\title{
THE POLITICS OF THE 2005 PARLIAMENTARY ELECTIONS IN ZIMBABWE
}

\author{
By \\ Choice Ndoro
}

Choice Ndoro is a member of the Department of Politics and Administration at the University of Zimbabwe

167 Mt. Pleasant, Harare, Zimbabwe

$\mathrm{Tel}+$ 263(4) 91316055

e-mail: cndoro@konsult.co.zw

\begin{abstract}
The political and legal framework governing the 2005 parliamentary elections played a significant role in determining the freeness and fairness of the elections. The repressive legislation and partisan institutions put in place to govern the previous two elections were perpetuated, with new names, new personalities and invigorated allegiance to the ruling party. The continued use of repressive institutions and legislation appears to stem from the ruling party's insecurity and its desire to maintain its hegemonic position. The establishment of the SADC Principles and Guidelines Governing the Conduct of Democratic Elections was both a timely and welcome development for civil society organisations and human rights activists. The government of Zimbabwe responded by selectively applying critical tenets of the guidelines. Undoubtedly there was a relative reduction in state-organised violence but repressive legislation designed to favour the ruling party was not dismantled. New but partisan electoral bodies were appointed to manage the elections and there was rampant and excessive executive interference in the operations of the electoral bodies. As a result the manner in which the delimitation process was conducted compromised the electoral result. The media were biased throughout the campaign period, only improving a few days before the poll. The voters' roll was a shambles, with names duplicated or omitted and including the names of deceased or nonexistent voters The announcement of the results in the absence of political party representatives raised suspicions about their validity. Civil society organisations and opposition political parties dismissed as a fraud an election that must be characterised as flawed - it was free but not fair.
\end{abstract}

\section{INTRODUCTION}

Parliamentary elections in Zimbabwe take place every five years and the 2005 elections were the fifth since independence. The preceding two elections were 
marked by structural and organised violence, with the ruling party, having assumed a hegemonic position, fighting against the popularisation of a newly formed opposition party with the capacity to threaten its primacy.

The ruling party's insecurity gave rise to repressive and monolithic state politics with intimidation, torture, intolerance, human rights violations and killings marking elections. This situation was backed up by repressive legislation and partisan institutions put in place to justify it. Dissenting voices from regional and international states as well as from national civil society organisations resulted in the Southern African Development Community (SADC) putting in place Principles and Guidelines for the Conduct of Democratic Elections (SADC guidelines). The Zimbabwean government had to decide whether to maintain power through the continued use of massive amounts of violence and risk political isolation or to embrace regional guidelines and gain support from regional brothers and sisters. A middle-of-the-road approach was adopted whereby the government did not dismantle the repressive legislation that had been put in place to govern previous elections but went on to set up electoral institutions according to the SADC guidelines.

Though it was prudent of the government to adhere to the guidelines, the existence of repressive legislation nullified many of the gains, creating suspicion and mistrust between government and civil society, which viewed the newly formed electoral institutions as biased, subjective and partisan. Suspicions were aggravated when legislation to establish the institutions revealed rampant executive interference in the functioning of the electoral bodies.

Analysis of the 2005 parliamentary elections without an analysis of the socioeconomic and political landscape would be inadequate as the latter forms the basis for the former. This paper therefore expounds on the role of the economic, political, legal and institutional framework as the basis from which the 2005 elections can be assessed.

\section{The Political and Legal Framework of the Elections}

At independence, Zimbabwe inherited the second most advanced economy in Africa. It was not only diversified, it was also highly integrated at the domestic level, with an equally high industrial output, large basic iron and steel capacity and sound agricultural surpluses. Health, education and other socio-economic indices were well above those of its Southern African neighbours (Good 2002, p 1).

Inappropriate policy priorities, bad economic management and the Zimbabwean government's flawed implementation of the policies of the International Monetary Fund (IMF) and the World Bank (WB) resulted in economic decline, with shortages of basic commodities, unemployment reaching 70 per cent and triple-digit inflation. This resulted in general discontent and dissenting voices among civil society organisations, academics and labour bodies, among others, and in September 1999, a new opposition party, the Movement for Democratic Change 
(MDC), was formed, deflating the myth of the omnipotence of the ruling Zimbabwe African National Union-Popular Front (ZANU-PF) party, which had enjoyed a political monopoly since independence.

In 2000, barely a year after the formulation of the MDC, the opposition scooped 49 per cent of seats in the parliamentary elections (Good 2002, p 24). For the first time since independence a party posed a serious threat to ZANU-PF's hegemony.

The ruling party's response to the near seizure of power was vicious and unrestrained violence against opposition supporters and civilians. ZANU-PF, which had been a militant and authoritarian liberation war movement, invoked these tendencies in reaction to the political threat posed by the MDC. Both the 2000 and 2002 elections were marked by structural and organised violence involving the army, the military and paragovernmental wings, including ruling party supporters. In the 2002 presidential election, 36 people were killed and thousands injured; 7000 people were displaced and intimidation, electoral manipulation and violence were recorded (Good 2002, p 24)

After the SADC guidelines were put in place it became apparent to the ruling party that it could not continue to use its previous strategies and it embarked on tabling new statutes and amending others in order to gain an advantage over the opposition.

The Public Order and Security Act (POSA) was a possible derivative of the Law and Order Maintenance Act (LOMA) introduced during the colonial era in order to suppress any form of civil unrest. POSA provides for the prosecution of journalists, media houses and individuals for making statements that are perceived to cause 'fear, alarm or despondency'. The Act, which also criminalises statements or acts that bring the president, the government or the Constitution into disrepute, is vague and has been used as a tool of repression. The first half of the election period saw the victimisation of MDC leaders and supporters but as international and regional bodies continued to emphasise SADC principles, the later part of the election period saw a dramatic reduction in violence.

The Access to Information and Protection of Privacy Act (AIPPA) 2005 was another piece of legislation put in place to oppress opposition political parties. The Act provides for the appointment of a Media and Information Commission (MIC) and criminalises journalists who practise with no accreditation. It also gives the Minister of Information and Publicity power to suspend journalists for one of a number of specified reasons. The rationale given by the state for promulgating the Act was to protect it from 'attacks' by enemies of the country. However, the Act resulted in the barring of all foreign journalists who were permanently working in Zimbabwe as well as the closure of four independent newspapers and the arrest of journalists working for independent newspapers.

A plethora of other legislation that had a bearing on elections included the Political Parties (Finance Act) of 1997, an amended form of the Political Parties Act No 14 of 1992, which allowed a political party with at least 15 seats in Parliament to benefit from state funding. The Act was amended by means of a court order which 
reduced the quota to five per cent of votes to enable more political parties to benefit from state funding. The MDC could now receive election funds from government which were more or less equal to those given to ZANU-PF.

The Broadcasting Services Act of 2002 regulated the conduct of the public media during the election. Although the Act gave responsible and equal opportunities for broadcasting election material to all parties contesting the election, in reality the public media were heavily skewed towards the status quo. A constitutionality challenge brought to the courts by Capital Radio resulted in the Act being labelled unconstitutional. The government reacted by striking down the Act and reintroducing it after six months through the Presidential Powers (Temporary Measures) Act. This resulted in biased reporting and deliberate misrepresentation of political issues. It was very clear during the election that ZANU-PF had a clear advantage in political processes. POSA, AIPPA and the Political Parties (Finance) Act, were specifically put in place in order to diminish the popularity of opposition parties (The Independent 5 March 2005).

Presidential appointments to the MIC and the letter and spirit of the Act appeared to be in gross contradiction of the SADC guidelines. The polarisation of society, closing down of independent radio stations and monopolisation of information by the state media marked the 2005 parliamentary elections. The MIC was mandated to edit and evaluate programmes for political parties, deciding what was acceptable and what was not. The right to edit programmes was reserved for a partisan government parastatal, which was biased against opposition parties.

Basic values and principles governing public administration entail promoting and maintaining a high standard of professional ethics as well as the provision of services that are impartial, fair, equitable and free of bias. This was not the case with institutions mandated with administrating the 2005 parliamentary elections. A successful election is not merely one in which everything works smoothly on election day, but one in which the legal environment and the systems it builds are equitable.

\section{ELECTION AdMINISTRATION}

Section 58(4) of the Constitution makes provision for an Electoral Act to be put in place in order to conduct elections. The Electoral Act Chapter 2(13) sets out the bodies mandated to conduct elections in Zimbabwe - they constitute a complicated tripartite system. Following the SADC guidelines, Zimbabwe established the Zimbabwe Electoral Commission (ZEC), an independent authority, to administer and supervise elections and referendums. The commission consisted of a chairperson, who is a judge of the Supreme Court and was appointed by the President in consultation with the Judicial Service Commission. The President also appointed four other commissioners (two of them women), from a list of seven submitted by the Committee on Standing Rules and Order which is a parliamentary committee (ZEC 2005). 
The functions of the ZEC were to prepare for and conduct efficiently and transparently presidential, parliamentary and local authority elections as well as referendums. The body was also mandated to direct and control voter registration, to compile voters' rolls and to conduct voter education and safeguard ballot papers and election materials (ZEC 2005). The ZEC also had the mandate to give instructions to the registrar-general voters and to keep the public informed about delimitated constituencies and other electoral matters as well as about political parties and candidates contesting the election.

When confusion arose between the newly established body and the existing body, the Electoral Supervisory Commission (ESC), which had the same general mandate, the Act was amended to give the ESC a supervisory and coordinating role, thereby ensuring it total control of the electoral process.

While the ESC was the supreme body conducting the elections, in practice the ZEC became the overall and supervisory body with total electoral control. The late establishment of the ZEC had a negative effect on election management, with the ZEC failing to carry out the initial tasks assigned to it, like the registration of voters, the maintenance of voters' rolls and registers, announcement of election boundaries and facilitation of the nomination of candidates and political parties, all of which activities were carried out by the registrar-general voters. When ZEC officials were finally appointed, they initially had no offices, telephones or vehicles. It was only at the voter education phase that the commission became active (Interview with a ZEC official 13 February 2004).

One of the threats to impartiality and transparency is posed by the fact that the president appoints all electoral bodies in Zimbabwe. The registrar-general voters has been a civil servant for 20 years and, despite allegations of partisanship and electoral rigging, continues to play a prominent role. Confidence will have to be built up and mutual trust cultivated if this office is to continue to be involved in elections.

The ZEC Act can be interpreted to allow the president either to consult or not to consult with the Judicial Service Commission. Although stringent measures were put in place to protect the terms of officials of the ZEC it is worrying to note that, once again, it is the president who appoints the tribunal to investigate and terminate the functions of ZEC officials. Over the years, Zimbabwe has experienced the overbearing nature of the executive branch in elections and political processes.

The case of Roy Bennett serves to illustrate the lack of impartiality in some election bodies. Bennett, the Member of Parliament (MP) for Chimanimani, was insulted and degraded by a ruling party MP, who made racist remarks about him and his ancestors. Infuriated, he pushed the other man to the floor and was sentenced to a year in prison for contempt of Parliament, the first person in the history of Parliament to have such action taken against him (Daily Mirror 20 February 2005).

When his wife filed nomination papers on his behalf, the nomination court sought the guidance of the Electoral Court, another newly established institution, created to solve disputes. The court ruled that the jailed candidate might run for 
election. That evening, President Robert Mugabe attacked the court's ruling, making further racist attacks on Bennett, stating that Zimbabwe would not be held to ransom by an 'arrogant Rhodesian'. The following day, the court reversed its decision and barred Bennett from standing (Daily Mirror 20 February 2005).

Presidential appointees in Zimbabwe tend to fail the impartiality test. Legislation that allows for executive involvement and interference in the elections reduces the level of democracy.

Electoral administration in Zimbabwe is unnecessarily complex, cumbersome and expensive. It is recommended that only one electoral body, which is non-partisan, transparent and genuinely accountable to the electorate, be put in place. If an election is to be free and fair participants should not be in a position to set the standards for the conduct of that election. Legislation should be amended to allow a genuinely non-partisan body to administer elections. Regional and international jurisprudence recognise that elections are an important part of good governance and electoral institutions and constitutional amendments should intensify democracy, not threaten it. Electoral amendments made in relation to the 2005 election compromised legitimacy instead of extending it. The SADC guidelines are silent on oppressive legislation that compromises the conduct of democratic elections, an oversight that renders the guidelines useless in the face of authoritarian regimes.

\section{Delimitation of Constituency Boundaries}

Gordon (1997) notes that the creation of electoral districts through a process of delimitation or demarcation is essential in a democracy to protect the principles of 'equal weight for each vote'. Boundaries must be drawn on a non-political basis to divide the total electorate into units of more or less equal population size. True to this specification, the government of Zimbabwe divided the country into 120 constituencies of about 46000 people each (Report of the Delimitation Commission 2004). Allegations of gerrymandering of election boundaries were made soon after the report was made available to the president. The allegations appeared to stem from the fact that the composition of the Delimitation Commission, which is composed of presidential appointees who are alleged to be partisan and subjective, is questionable. Areas that lost constituencies were strongholds of the opposition, while the ruling party strongholds gained seats. This was contrary to census statistics and the theories of rural to urban migration. The conclusion drawn by critics was that the delimitation process was conducted to benefit the ruling party (Report of the Delimitation Commission 2004).

\section{VIOLENCE AND INTIMIDATION}

As a result of legislation put in place to disadvantage the opposition, the initial phase of the electoral period saw intimidation of opposition supporters by the police and over-zealous ruling party youths. 
It was only after the President and the Commissioner of Police made calls for the violence to end that ruling party youths, used to committing acts of violence with impunity, ceased to do so. Tremendous pressure on the government to adhere to the SADC guidelines resulted in the arrest of violent ruling party supporters, a development unknown in the previous two elections. As a result, all political parties were able to conduct campaign rallies in the rural areas and basic human rights standards were observed (Daily Mirror 20 March 2005).

\section{Primary Elections}

Intra-party primary elections were conducted according to the constitutions of the individual parties, with the two biggest parties in Zimbabwe confronted with similar problems - allegations of vote buying, vote rigging, and factionalism resulting in dissent, resignations and dismissals from the parties.

In the MDC, two-thirds of members in the local structures confirm a sitting $\mathrm{MP}$ and if the member is not confirmed, other aspirant candidates will tender their curriculum vitae for consideration. Accusations of factionalism, mud slinging and outright rigging of primary elections were levelled against top election officials of the party and only five of the 120 MDC MPs were not confirmed (Interview with the MDC Directorate 1 March 2005).

Democratic values should not be encouraged only at the national level but also at party level. Political parties cannot be undemocratic at party level and cultivate democratic values at national level. Political parties that are undemocratic at party level cannot be trusted with higher authority.

ZANU-PF involves all its supporters, who vote for party candidates at local level. The candidate with the majority of votes represents the party in the national elections. Imposition of candidates, selective application of justice, vote buying, violence, intimidation and faction fighting characterised the ZANU-PF primary elections and 17 of the 120 constituencies had to rerun their elections. Of the 1000 people who submitted their CVs to contest the primary elections, only 117 were accepted (Interview with ZANU-PF candidate for Gutu South 15 March 2005).

The criteria for selection were questionable. When the party realised that party 'heavyweights' had been trounced by their juniors at local level, new criteria were put in place to ensure that senior members of the party were automatically selected. It was ruled that no members who had sat in the Politburo, the Central Committee or at provincial level needed to contest the primary elections. This caused a great deal of dissatisfaction among the 'Young Turks', who had spent time and money campaigning for seats. Besides, the senior members were likely to lose because they were unpopular with the masses, who believed most of them had done little about development in the past 25 years (Interview with ZANU-PF candidate for Gutu South 15 March 2005).

The manifestos of both parties were plausible and addressed key macroeconomic, political and social issues. Both were concerned with reducing inflation, 
managing public debt, reviving collapsed industries and reorganising the agricultural sector. The MDC extended its manifesto to include bringing about the rule of law, respect for human rights and a new constitution (MDC Manifesto 2005).

The ZANU-PF campaign departed slightly from the norm. Dubbed the AntiBlair campaign, it emphasised national autonomy, sovereignty, social justice and redistribution of wealth and dealt more with external political issues than with national challenges. ZANU-PF put in place a quota system for women, a development that caught the MDC off balance. Human rights and women's organisations as well as party supporters and academics viewed the adoption of the SADC declaration on gender and development that calls for the allocation of 30 per cent of seats to women as an important step towards the empowerment of women (ZANU-PF Manifesto 2005).

\section{Political PARTy FinANCING}

In 1992 Parliament enacted the Political Parties (Finance) Act No 14. According to the provisions of the Act, parties that won at least 15 seats would be given financing. The United Parties, an opposition party, challenged the 15-seat threshold in the Supreme Court, calling it unconstitutional and the court reduced the threshold to 5 per cent of the votes. This amendment was incorporated through the Political Parties (Finance) Amendment Act No 20 of 1997. The Act enabled the MDC to receive state funds for its 2005 parliamentary campaign.

The finances allocated to both political parties were grossly inadequate to cover the entire election process. Fees for the registration of aspiring candidates were increased from US\$20 per candidate to US\$400. A political party fielding 120 candidates would have to pay US\$48 000. Access to the print and electronic media was also affected when fees were hiked. Only two major political parties were able to field all 120 candidates and air their programmes. Some minority parties withdrew their candidates or aired only a few programmes (Media Monitoring Project Zimbabwe 20 February 2005).

Although there was legislation to criminalise private funding, the major political parties openly flouted this restriction. Allegations of the use of state resources were levelled against the ruling party. It is a generally accepted rule of democracy that, in order to level the playing field, the resources available to government should not be made available to the ruling party. However, as in previous Zimbabwean elections, on this occasion there appeared to be no separation of state and ruling party assets, with state helicopters used to conduct campaign rallies. Viewers who saw the Zimbabwe Broadcasting Corporation News on 15 March, for instance, observed that vehicles, civil servants, schools, clinics and other state material, institutions and personnel were used by the ruling party in its campaign processes.

The Government of Zimbabwe should be commended for putting in place institutions and processes not previously in use in order to comply with the SADC 
Principles and Guidelines. These include the financing of opposition parties, voter registration, candidate nomination and a multi-liaison committee stipulating specific rules of conduct and regulations governing election broadcasting. However prudent the gesture may be, there is a great deal of work to be done to ensure that the institutions are not only impartial, objective and non-partisan but that they are seen to be so.

\section{An Analysis of Media Coverage During THE ELECTION CAMPAIGN}

Democratic, free and fair elections depend on the existence of free, informed and responsible media. If the media do not play an active role in observing, investigating, analysing and publicising all phases of the election process, it is difficult for them as a whole to hold the authorities and other stakeholders accountable. The media should accept their role in developing a culture of openness and tolerance, which is essential for free political activity. Good election practice dictates that the free media should have equal access to information about election processes and procedures (Gordon 1997, p 4).

The media, in turn, must take responsibility for making information available to the public and providing balanced coverage of election campaigns, by reporting on the positions of all contesting parties and offering objective analysis. Uneven coverage by the media, partisan access and uneven distribution of resources undermine smaller political parties.

Access to the media is crucial to the dissemination of party programmes and this access should not be impeded. Candidates should enjoy the right to free expression and opinion without intimidation, victimisation or imprisonment (Gordon 1997, p 4).

The media in Zimbabwe were heavily biased in favour of the ruling party throughout the campaign process. The government-owned print media naturally aligned themselves with the ruling party. With the closure of three independent newspapers and the bombing of another, the electorate was left with little choice but the government newspapers. These are heavily politicised and any journalists who appeared to be objective were transferred or relieved of their duties. There was deliberate misrepresentation of the opposition parties' policies and objectives (Human Rights Forum Report 2005).

The national television service was biased and heavily aligned with the ruling party until a month before polling day, when it opened up the airwaves to all contesting parties. In February 2005 the public media carried news of 33 campaign star rallies (major rallies usually addressed by presidential candidates and highranking party officials), 73 per cent related to the ruling party and reported positively on it while only 18 per cent focused on the major opposition party, the MDC, and 3 per cent were neutral reports on minor parties and 6 per cent covered unspecified matters. Coverage of the opposition parties was negative and intended to undermine 
them. During the same period television presenters were seen adorned in ruling party regalia while presenting the evening news, a clear violation of election neutrality (Media Monitoring Project Zimbabwe 20 February 2005).

Apart from the Independent, the private press consisted of the Sunday Mirror and the Daily Mirror, both owned by a ruling party sympathiser. The weekly paper was initially biased towards the opposition and carried stories heavily criticising the ruling party and glorifying the proposed policies of the opposition. The daily paper owned by the ruling party sympathiser was slanted towards the ruling party initially, but when the paper's sales started declining, it became objective and even critical of government policy, before swinging back again soon after the elections to criticise the opposition.

The electorate was bombarded with presentations and analyses by 'academics' who unashamedly humiliated and attacked opposition candidates. The Minister of Information and Publicity interpreted the Broadcasting Services Act to give the Zimbabwe Broadcasting Holdings $(\mathrm{ZBH})$ the mandate to allocate airtime and to have the discretion to allow opposition parties reasonable access. He reiterated that opposition parties had no right to claim access as a result. Regulations governing the broadcasting of election material decreed that all advertisements which incite or perpetrate hatred of any group on the basis of its political affiliation will not only not be aired but will be criminalised. The regulation was clearly flouted throughout the campaign process by the ruling party, who called the main opposition party imperialists and stooges of the West (The Herald 9 March 2005).

\section{Civic And Voter Education}

No democratic system can function well without an educated and informed citizenry. The SADC guidelines stipulate that civic and voter education is grounded in citizen participation in decision-making processes, thereby consolidating democratic practice.

Given the high illiteracy levels in African countries voter and civic education play a paramount role in moulding democracy. Non-partisan, independent and consistent education enables voters to make informed choices. While civic education centres on information dissemination about basic rights and responsibilities as well as fundamental freedoms, it also involves an understanding of how government works, as well as holding accountable elected government officials.

Voter education is a sub-discipline of civic education. Its object is to promote high levels of informed and effective participation by all eligible voters. It should also help foster political tolerance amongst the electorate, emphasising the merits of respect and observing other people's rights. Voter education programmes should be political, professional, comprehensive and simple enough to be accessible. Piroshaw Camay (1997) notes that voter and civic education results in higher voter turnout and reduced numbers of spoilt ballot papers. 
Voter education, a vital component of freedom of expression, which is considered the foundation of a democratic society, was the prerogative of the newlyformed ZEC, which was supposed to be apolitical. However, the ZEC's operations were severely curtailed by its late appointment as well as by a lack of mobility and it only started its voter education campaign less than a month before the elections, a clear violation of democratic ethos. Three weeks before polling day the Commission had no vehicles, offices or contact details. Consequently voter education was concentrated in the urban areas and conducted by means of pamphlets, posters, and radio and television announcements. As a result, large numbers of voters were turned away and a record number of ballot papers were spoilt.

Civic education also proved a problem. Non-governmental organisations (NGOs) were able to conduct it at workshop level for urban organisations but they were unable to access the wider populace because to do so was viewed as detrimental to the nationalist philosophies of the ruling party. The urban populace, however, was able to attend various meetings organised by NGOs in the central business district, mostly in hotels. Almost no civic education reached the rural areas, where there are more illiterate people than in urban areas.

The government's hostility to civic education can be attributed to the fact that it considered human rights and democratic principles to be Western imperialist devices intended to 'destabilise', 'polarise' and 'recolonise' the country. Individuals and organisations registered to implement human rights programmes were threatened with closure. An NGO Bill was drafted requiring all NGOs to register and those registered as trusts ceased to be lawful and were forced to stop functioning and re-register under a new legal instrument. All NGOs concerned with issues of governance and human rights were to be deregistered (s 9 of the NGO Bill).

The period before the 2005 elections was marked by confusion in the NGO sector, with NGOs uncertain about their survival after the election. As a result most of them were concerned with strategising and re-registration pursuits in anticipation of the passage of the Bill.

The result of the uncertainty was that the donor community held back funds, severely curtailing both civic and voter education. At the time of writing, the Bill had not passed through Parliament (Interview with ZESN official 6 March 2005).

If there is a lesson to be learnt from the Zimbabwean experience it is that voter education should be all-inclusive and be conducted by civil society, NGOs, academics, student bodies, churches, women's organisations, and the youth, among others. The number of people turned away because their names did not appear on the voters' roll, because they had inappropriate identity cards or because they went to the wrong constituencies was alarming. The percentages of voters turned away ranged between 9 per cent and 17, 7 per cent, an unacceptable percentage by any standard. This could have been a strategy employed by government to protect Zanu's rural strongholds from MDC infiltration (The Herald 8 April 2005). 


\section{Election ObServation}

The need for international observers derives from several sources. They provide psychological support to participants in the election process. The mere presence of observers reassures a sceptical population about the secrecy of the ballot, the efficacy of the process and the safety of voters. Observers may also prevent fraud during the balloting and counting process and can report to the international community on the overall fairness of an election process (McCoy, Garber \& Pastor 1993).

International election monitoring raises delicate questions of national sovereignty. Some African leaders consider the very idea to be in conflict with the principle of non-intervention, which is closely guarded by many today. Most African leaders viewed North-South election monitoring as vital during decolonisation, but now believe it is irrelevant and smacks of colonialism and the destabilisation of African states by the West. This notion is reinforced where the presence of international observers has coincided with regime change. African governments have therefore not always welcomed election observation outside the decolonisation context (McCoy, Garber \& Pastor 1993, p 16).

The 2005 elections in Zimbabwe were held at a time when relations between Britain and Zimbabwe were at their lowest. The antagonism began in 2000 when the government drafted a proposed new constitution, which was seen by NGOs as intensifying the powers of the president. The legislation also gave the government the right to acquire land without compensation - a result of British Prime Minister Tony Blair's refusal to adhere to an agreement to compensate white farmers for the loss of their land. NGOs campaigned heavily against the draft constitution and Zimbabweans voted overwhelmingly against it in a referendum.

The stand-off resulted in government-organised land invasions, which displaced white farmers and compromised food security. The deteriorating relationship between Britain and Zimbabwe resulted in a campaign process so riddled with slogans of anti-colonialism, sovereignty and patriotism it might have been believed that Britain was a competing political candidate. Blair's announcement, in response to a question in Parliament that he intended to bring about a regime change in Zimbabwe was received with outrage by the ruling party (Cable News Network 2002).

Zimbabwe's response was to omit the European Union, the Commonwealth and Western countries from the observations teams, choosing, instead, African countries and revolutionary organisations. Also included were countries that were perceived to be neutral and with nothing to do with the political situation in Zimbabwe - South American, Asian and Caribbean countries. Russia and China were chosen because of their long-standing relationship with the ruling party and their socialist ideology (The Herald 20 March 2005).

Zimbabwe employed a sophisticated system of accrediting observers. The Ministry of Justice, Legal and Parliamentary Affairs issued invitations and wouldbe observers were to submit their credentials to the ministry and be accredited by 
the ESC upon production of an invitation letter and payment of a levy. All accredited observers would be expected to submit a preliminary report after the closure of polls, before the count, and the final report within 14 days of the count (The Herald 21 March 2005).

Clearly both Western and African countries, with their strong political interests in the outcome of the election, had pre-judged it and neither bloc was likely to give an objective analysis.

Observers arrived only three weeks before polling day, contrary to the 90 days stipulated in the SADC guidelines, a possible result of the late issue of invitations. Critics speculated that the reduced period gave the government adequate time to deal with isolated incidents of violence before the observers arrived.

\section{Voter Registration AND NominAtions}

The registration of voters, together with the nomination of parties and candidates, was conducted in line with the SADC guidelines. Voter education was conducted on the requirements for registration and voters had no problems registering. International requirements demand that the registration of voters must be carefully conducted to ensure fairness and effectiveness of provisions concerning qualifications, residence requirements and voters' rolls. The procedures put in place in the 2005 parliamentary elections did not create unnecessary technical barriers to participation.

The nomination of parties and candidates was conducted according to the law of the land. Save for the problems caused by the exorbitant fees stipulated by the ZEC, all political parties were able to register. Nominations were conducted in a transparent manner. In previous elections many opposition candidates had been barred from submitting their nomination papers, while some found physical barriers erected on roads leading to nominations courts and others were thoroughly beaten or abducted and held until the courts closed. No such occurrences were recorded in the 2005 elections. There were no unreasonable restrictions placed on the registration of parties and candidates. The law was followed in terms of party names and symbols. Procedures for designation of party agents were clearly established by the Electoral Act.

Election material used in the 2005 elections met with international standards and was in line with the SADC guidelines. Translucent ballot boxes were used, voting booths ensured security and indelible ink was visible and only faded after three weeks. Ballot papers were clearly numbered with visible political emblems and symbols. Lanterns, candles and matches were dispatched to illuminate polling areas. Mobile booths were outlawed, as they were viewed as offering opportunities for vote rigging. Election agents, polling officers and presiding officers were well trained and efficient in their conduct (Interview with MDC Election Directorate official 1 April 2005). 


\section{Polling, Counting and Announcement of Election Results}

Polling day was peaceful, with only isolated and minor cases of violence recorded. Unlike in previous elections, where there were deliberate attempts to frustrate the urban voters, the 2005 elections were conducted efficiently. The reduction of voting days from three to one was in line with the SADC guidelines and assisted in creating confidence among voters that there was unlikely to be electoral fraud. The increase in the number of polling stations greatly improved efficiency and effectiveness. The secrecy of the vote was respected at all times. Voting procedures were designed to encourage broad participation. Voters with special needs, including the disabled, the elderly, and foreign- service personnel, were assisted in a professional manner (Interview with MDC Election Directorate official 1 April 2005).

It was the counting of ballots that caused divisions and discontent in the country, the region, and even internationally. The National Command Centre, where election results are announced, is staffed by government officials and the law prevents any election agents or representatives of political parties from being present. By midday, the ZEC had announced that most registered voters had cast their votes. Live coverage of events taking place in the country was conducted through both the radio and national television. At 19:30, 30 minutes after voting had officially concluded, the Chairman of the ESC began to announce through the media the total number of votes cast in each constituency. After more than 30 constituencies had been announced, the exercise stopped abruptly, with no explanation. When the final results were announced, there were massive discrepancies between the original figures announced for the constituencies and the final figures. In some cases, the figures announced at the end of polling were lower than those that had been announced during polling. Attempts to explain the discrepancies were not convincing and opposition parties, some NGOs, and some international states rejected the results, calling them the most fraudulent in the history of Zimbabwe.

There were further allegations that some results of constituencies were announced before the counting was completed. Reports from opposition election agents noted that some agents for ruling party members brought in figures for postal ballots. The major problem was that the presiding officers, who, in most cases, were government employees, would not want to question or reject directives of senior ruling party officials who were often their superiors. Although these allegations were never confirmed, the majority of Zimbabweans, both rural and urban, perceived that they had been cheated once more (Human Rights Forum 1 April 2005).

Although the results were received with political maturity, despondency and hopelessness continued to grip Zimbabweans in the face of an economy that maintained its nosedive. Election petitions are not likely to be resolved in the near future as courts have not cleared petitions filed in relation to the 2000 and 2002 elections. Regional and international leaders who tried to facilitate dialogue were 
lambasted by the President for meddling in Zimbabwe's affairs (The Herald 15 April 2005).

Soon after the elections, government embarked on an operation called 'Restore Order', during which illegal houses, cottages and shacks were destroyed in order to 'clean up' the cities. Housing schemes belonging to war veterans who had helped the ruling party secure victory in three elections were ravaged amid speculation that the move was intended to curb the powers of the war veterans in the face of their demands to be included in the Senate. Another school of thought is that the operation was intended to 'dilute' urban voters who had voted for the opposition ever since its inception. After a visit, the UN Special Envoy on Human Settlements, Alice Tibaijuka, produced a damning report revealing that the national budget included no item for housing which would enable the evicted citizens to be rehoused. The government, however, insisted that the protests were part of a plan by the West to discredit the Zimbabwean government's noble attempts to restore order and provide better accommodation, an unlikely explanation in light of the facts contained in the report (Tibaijuka 2005).

\section{CONCLUSION}

The same legal framework that governed the 2000 and 2002 elections is still in place today and has compromised basic freedoms and fundamental rights. Although the government put in a great deal of effort to ensure that the elections were free and fair and to adhere to the SADC Principles and Guidelines, a lot of political will will have to be nurtured to ensure that there is no gerrymandering of constituency boundaries, that the voters' roll is revamped, that any statute or constitutional provision that compromises human rights is struck down, and, finally, that the announcement of results is never manipulated to enable a single party to benefit. It should also be noted that, though elections themselves are a good measure of democracy, they are only one vital component; they are not an end in themselves but a means to an end. Genuine political will is vital to bring about democratic institutions and processes. As a result, the 2005 parliamentary elections were free but not fair.

\section{REFERENCES}

\section{Publications}

Camay, P. 1997. Principles of Election Practice. Johannesburg: Core.

Good, Kenneth. 2002. 'Dealing with Despotism: The people and the Presidents'. In Henning Melber (ed). Zimbabwe's Presidential elections 2002: Evidence, Lessons and Implications. Uppsala: University Printers.

Goodwin-Gill, G S. 1994. Free and Fair Elections: International Law and Practice. Geneva: Inter-Parliamentary Union. 
Gordon, A J. 1997. Principles of Election Practice. South Africa: Co-operative for Research and Education.

Gula-Ndebele, S. 2000. Report on the 2000 Parliamentary elections. Zimbabwe: Electoral Supervisory Commission.

Inter-Parliamentary Union, The. 1998. Codes of Conduct for Elections. Geneva: InterParliamentary Union.

Makumbe John. 2002.Zimbabwe's Hijacked Elections, Journal of Democracy 13(4), October.

Melber, H. 2002. Zimbabwe's Presidential Elections; Evidence, Lessons and Implications. Sweden: Nordiska Afrikainstitutet.

NORAD. 1999. Gender Checklist for Free and Fair Elections: A Handbook. Johannesburg: EISA.

Centre for Human Rights. 1994. Human Rights and Elections: A Handbook on the Legal, Technical and Human Rights Aspects of Elections. New York, Geneva: Centre for Human Rights.

Southern African Elections Forum. 2000. In Pursuit of Electoral Norms and Standards, 11-14 June.

Media Monitoring Project of Zimbabwe, 20 February 2005.

SADC Principles and Guidelines Governing the Conduct of Democratic Elections, August, 2004.

\section{Media}

Cable News Network (CNN).

Daily Mirror.

Herald, The.

Independent.

Zimbabwe Broadcasting Corporation News.

\section{Reports}

Delimitation Commission Report 2004.

Human Rights Forum 1 April 2005.

Media Monitoring Project Zimbabwe 20 February 2005.

Tibaijuka, A K. 2005. Report of the Fact-Finding Mission to Zimbabwe to assess the Scope and Impact of Operation Murambatsvina by the UN Special Envoy on Human Settlements. Harare, 18 July.

\section{Legislation}

Access to Information and Protection of Privacy Act 5 of 2003, Chapter 10:27.

The Electoral Act, 2005, Chapters 2:01 and 2:13.

Political Parties Finance Act 14 of 1992

Political Parties Finance Amendment Act 20 of 1997.

Public Order and Security Act 1 of 2002, Chapter 11:17.

Non-governmental Bill, 2002. 


\section{Interviews}

MDC Directorate official, 18 February 2005, 27 February 2005, 1 March 2005, 16 March 2005.

ZANU-PF candidate for Gutu South, 15 and 21 March 2005.

ZEC official, 13 February 2004.

ZESN official, 1 March 2005.

ZESN official, 6 March 2005.

\section{Manifestos}

MDC 2005

ZANU-PF 2005 